Reviu Akuntansi dan Bisnis Indonesia, Vol. 1 No. 1, Hlm: 25-35, Juli 2017

Website: http://journal.umy.ac.id/index.php/rab

\title{
Pengaruh Perceived Usefulness, Perceived Ease of Use, Perceived Enjoyment, dan Actual Usage Terhadap Penerimaan Teknologi Informasi: Studi Empiris Pada Karyawan Bagian Akuntansi dan Keuangan Baitul Maal Wa Tamwil Wilayah Daerah Istimewa Yogyakarta dan Sekitarnya
}

Elok Irianing Tyas; Emile Satia Darma

Program Studi Akuntansi Universitas Muhammadiyah Yogyakarta

I N F O A R T I K E L

Kata Kunci:

Persepsi Kegunaan,

Persepsi Kemudahan

Sistem, Persepsi

Kenyamanan, Pemakaian

Nyata, Sikap Pengguna,

Penerimaan Teknologi

Informasi

Jenis Artikel:

Penelitian Empiris

Correspondence:

emile@umy.ac.id

\author{
A B S T R A K
}

Penelitian ini bertujuan untuk menguji pengaruh perceived usefulness (persepsi kegunaan), perceived ease of use (persepsi kemudahan sistem), perceived enjoyment (persepsi kenyamanan), dan actual usage (pemakaian nyata) terhadap penerimaan teknologi informasi pada karyawan bagian akuntansi dan keuangan yang ada di BMT Wilayah Daerah Istimewa Yogyakarta dan sekitarnya. Variabel independen dalam penelitian ini terdiri dari persepsi kegunaan, persepsi kemudahan sistem, persepsi kenyamanan, dan pemakaian nyata. Sedangkan variabel dependen dalam penelitian ini adalah penerimaan teknologi informasi.

Teknik pengambilan sampel yang digunakan dalam penelitian ini adalah non- probability sampling. Dengan metode tersebut, peneliti menggunakan sampel sebanyak 40 responden. Pengujian statistic deskriptif, pengukuran outer model, validitas konvergen, validitas diskriminan, uji reabilitas, dan pengukuran inner model.

Hasil penelitian menunjukkan bahwa Persepsi kemudahan sistem (perceived ease of use) berpengaruh positif secara signifikan terhadap persepsi kegunaan (perceived usefulness). Persepsi kegunaan (perceived usefulness) tidak berpengaruh secara signifikan terhadap sikap pengguna (attitude toward using). Persepsi kemudahan sistem (perceived ease of use) tidak berpengaruh secara signifikan terhadap sikap pengguna (attitude toward using). Persepsi kenyamanan (perceived enjoyment) pengguna tidak berpengaruh secara signifikan terhadap sikap pengguna (attitude toward using). Persepsi kemudahan sistem (perceived ease of use) tidak berpengaruh secara signifikan terhadap pemakaian nyata (actual usage). Persepsi kegunaan (perceived usefulness) tidak berpengaruh secara signifikan terhadap pemakaian nyata (actual usage). Persepsi kegunaan (perceived usefulness) tidak berpengaruh secara signifikan terhadap penerimaan teknologi informasi (acceptance of IT). sedangkan Sikap pengguna (attitude toward using) tidak berpengaruh secara signifikan terhadap penerimaan teknologi informasi (acceptance of IT).

(C) 2019 RAB. Published by Universitas Muhammadiyah Yogyakarta 


\section{PENDAHULUAN}

Baitul Maal wa Tamwil (BMT) merupakan salah satu lembaga keuangan islam mikro yang paling terjangkau dan dapat membantu pengusaha kecil dan mikro untuk mengembangkan usahausaha yang produktif dan investasi untuk meningkatkan kualitas kegiatan perekonomian pengusaha kecil dengan mendorong kegiatan menabung dan menunjang kegiatan ekonominya. Namun terdapat beberapa hal yang menyebabkan lembaga ini kurang dapat menjangkau sasaran dengan tepat, salah satunya yaitu ketidakefisienan dalam penggunaan infrastruktur. Hal ini disebabkan oleh masih banyak BMT yang diperkirakan masih memanfaatkan infrastruktur yang masih sangat sederhana. Oleh karena itu, dilakukan berbagai upaya untuk meningkatkan sustainabilitas dari usahanya, sehingga mampu melayani masyarakat di pedesaan khususnya para pengusaha mikro dan pedagang kecil dengan lebih efektif dan efisien, maka perlu dikembangkan sistem pencatatan transaksi/akuntansi secara elektronik yang akan diterapkan pada BMT di Wilayah Daerah Istimewa Yogyakarta dan sekitarnya.

Perusahaan dapat memperbaiki kinerja organisasinya jika perusahaan tersebut menggunakan sistem teknologi informasi yang baru dengan efisien dan secara actual. Penggunaan sistem pencatatan/akuntansi baru dalam suatu organisasi akan berpengaruh pada keseluruhan organisasi, terutama pada sumber daya manusia. Faktor pengguna sangat penting untuk diperhatikan dalam penerapan sebuah sistem yang baru, karena tingkat kesiapan pengguna dalam menerima sistem yang baru memiliki pengaruh yang sangat besar dalam menentukan sukses atau tidaknya pengembangan dalam penerapan sistem tersebut (Kang, 1998).

Davis (1989) mengatakan bahwa tingkat penerimaan pengguna Sistem Teknologi Informasi (STI) dalam model Technology Acceptance Model (TAM) ditentukan oleh 6 konstruksi, antara lain: variable dari luar (external variable), persepsi pengguna terhadap kemudahan (perceived ease of use), persepsi pengguna terhadap kemanfaatan (perceived usefulness), sikap dalam menggunakan (attitude toward using), perhatian untuk menggunakan (behavioral intention to use), dan pemakaian nyata (actual usage). Hubungan antara ke-enam konstruksi tersebut dapat dilihat pada gambar 1 .

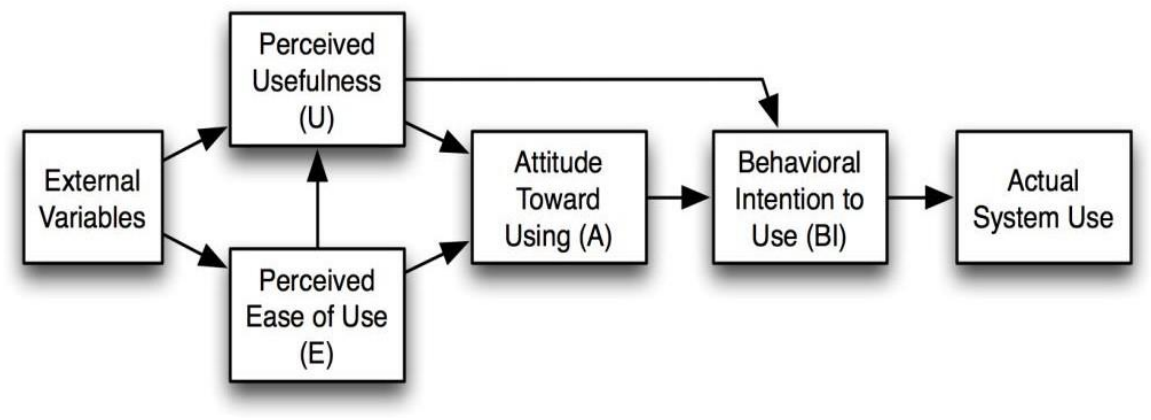

Gambar 1 Model Penerimaan Teknologi Sumber: Davis (1989)

Gambar 1 menjelaskan tentang hubungan antar konstruksi yang terdapat dalam TAM menurut Davis (1989), yaitu konstruksi external variable akan memberikan pengaruh terhadap konstruksi perceived ease of use dan bentuk perceived usefulness. Konstruksi perceived ease of use dianggap akan memberikan pengaruh terhadap konstruksi perceived usefulness. Selain kedua konstruksi tersebut (perceived ease of use dan perceived usefulness) sama-sama mempunyai pengaruh terhadap konstruksi attitude toward using. Konstruksi perceived usefulness akan memberikan pengaruh terhadap behavioral intention to use. Selain itu, behavioral intention to use akan dipengaruhi oleh konstruksi attitude toward using dan akan memberikan pengaruh pada actual usage sekaligus. 


\section{TINJAUAN LITERATUR DAN PERUMUSAN HIPOTESIS}

\section{Penerimaan Teknologi Informasi}

Kesuksesan sistem informasi diukur menggunakan empat jenis ukuran, antara lain kepuasan pemakai, penggunaan sistem, kinerja keputusan, dan kinerja organisasi. Goodhue dan Thomson (1995) mengatakan bahwa pemanfaatan dalam sistem teknologi informasi menunjukkan keputusan individu untuk menggunakan atau tidak sebuah sistem teknologi informasi tersebut dalam membantu menyelesaikan serangkaian tugasnya.

\section{Technology Acceptance Model (TAM)}

Davis (1989) menjelaskan tentang beberapa model yang dibuat untuk menganalisa dan memahami faktor- faktor yang mempengaruhi penerimaan penggunaan teknologi komputer, antara lain yang terdapat didalam berbagai literatur dan referensi hasil dari penelitian dibidang teknologi adalah seperti Theory of Reasoned Action (TRA), Theory of Planned Behavior (TPB), dan Technology Acceptance Model (TAM). Model TAM diadopsi dari model TRA yaitu teori tindakan yang mempunyai alasan dengan satu premis bahwa reaksi dan pandangan seseorang terhadap sesuatu akan menentukan seperti apa sikap dan perilaku orang tersebut. Reaksi dan pandangan pengguna teknologi informasi akan mempengaruhi sikapnya ketika menerima teknologi tersebut. Faktor yang mempengaruhinya yaitu pandangan pengguna terhadap manfaat dan kemudahan dalam menggunakan TI menjadikan perilaku pengguna tersebut sebagai parameter dalam penerimaan teknologi.

\section{Persepsi Kegunaan (Perceived Usefulness)}

Persepsi kegunaan (perceived usefulness) didefinisikan sebagai suatu tingkatan dimana seorang individu mempercayai bahwa menggunakan suatu sistem tertentu akan dapat membantu meningkatkan kinerja dan prestasi kerja individu tersebut. Berdasarkan definisi tersebut bisa diambil kesimpulan bahwa manfaat dalam menggunakan TIK dapat membantu meningkatkan kinerja dan prestasi kerja individu yang menggunakannya.

\section{Persepsi Kemudahan Pengguna (Perceived Ease of Use)}

Perceived ease of use merupakan sebuah teknologi yang diartikan sebagai suatu tolak ukur untuk seseorang yang percaya bahwa komputer dapat dipahami dan digunakan dengan mudah. Beberapa indikator yang dapat digunakan untuk mengukur perceived ease of use antara lain fleksibel, mudah dipelajari, mudah digunakan, dan dapat mengontrol pekerjaan.

\section{Persepsi Kenyamanan Pengguna (perceived enjoyment)}

Kenyamanan merupakan kondisi dimana seorang individu menggunakan sebuah teknologi ketika menjalankan aktivitasnya dan merasa nyaman untuk dirinya sendiri (Tangke, 2004). Nugraha et al., (2016) menjelaskan bahwa semakin tinggi tingkat kenyamanan yang dimiliki oleh pengguna teknologi informasi maka semakin baik sikap dari pengguna yang nantinya akan berkaitan dengan penerimaan teknologi sistem tersebut. Perasaan senang dan nyaman dalam menggunakan sistem teknologi informasi akan membuat pengguna melakukan pekerjaannya dengan baik dan menyelesaikannya tepat pada waktunya.

\section{Pemakaian Nyata (Actual Usage)}

Actual system usage merupakan bentuk respon psikomotor eksternal yang dapat diukur dari seorang dengan penggunaan nyata (Davis, 1989). Actual system usage memiliki konsep 
pengukuran terhadap frekuensi dan durasi waktu terhadap penggunaan teknologi (wibowo, 2006). Sedangkan menurut Rigopoulos dan Askounis (2007) actual usage diukur berdasarkan penggunaan teknologi secara berulang-ulang dan lebih sering.

\section{Sikap Terhadap Penggunaan (Attitude Toward Using)}

Sikap terhadap penggunaan dikonsepkan sebagai bentuk penerimaan atau penolakan sebagai efek dari seseorang yang menggunakan suatu teknologi dalam melakukan pekerjaannya (Davis, 1993). Sikap mencerminkan tentang sesuatu yang kita suka atau tidak (Widyarini (2005). Sikap seseorang terdiri atas unsur kognitif (cognitive), afektif (affective), dan komponenkomponen yang berhubungan dengan perilaku seseorang (behavioral components).

\section{Persepsi Kemudahan Sistem (Perceived Ease Of Use) dan Persepsi Kegunaan (Perceived Usefulness)}

Persepsi pengguna tentang kemudahan dalam menggunakan sistem didukung oleh sikap pengguna tentang kegunaan dari sistem tersebut. Hal ini dapat dipengaruhi oleh faktor masa kerja karyawan pengguna teknologi informasi dan masa implementasinya. Oleh karena itu, ketika karyawan menggunakan sebuah sistem teknologi informasi selama kurang lebih 5 tahun, maka karyawan akan menganggap bahwa STI yang telah mereka gunakan mudah digunakan karena mereka telah mengetahui kegunaan STI tersebut. Berdasarkan uraian diatas, maka dapat diturunkan hipotesis:

\section{$\boldsymbol{H}_{I} \quad$ :Persepsi Kemudahan Sistem (perceived ease of use) berpengaruh positif terhadap persepsi kegunaan (perceived usefulness) dalam pemanfaatan STI.}

\section{Persepsi Kegunaan (perceived usefulness) dan pengguna (attitude)}

Penggunaan suatu sistem teknologi akan memberi manfaat tertentu bagi penggunanya seperti memudahkan dalam penggunaan sehari-hari. Sebagai contoh, sebuah bank yang memberikan fasilitas internet banking kepada nasabahnya akan memberikan kemudahan bagi nasabah dalam melakukan transaksi keuangan. Nasabah yang sebelumnya harus datang ke bank untuk menjalani beberapa tahap dan mengantri, sekarang dapat melakukan aktifitas perbankan dengan lebih cepat dan mudah dengan menggunakan fasilitas internet banking, sehingga dapat menghemat waktu untuk melakukan tugas lainnya. Berdasarkan uraian diatas, maka dapat diturunkan hipotesis:

$\boldsymbol{H}_{2}$ : Persepsi kegunaan (perceived usefulness) berpengaruh positif terhadap sikap pengguna (attitude) dalam pemanfaatan STI.

\section{Persepsi Kemudahan Sistem (Perceived Ease Of Use) dan Sikap Pengguna (Attitude)}

Terbentuknya sikap seseorang untuk tetap menggunakan suatu sistem teknologi bergantung pada kemudahan yang diberikan oleh sistem tersebut, sehingga pengguna STI merasa bahwa STI yang digunakan dapat membantu meringankan tugas-tugas mereka. Berdasarkan uraian diatas, maka dapat diturunkan hipotesis:

$\boldsymbol{H}_{3} \quad$ : Persepsi kemudahan sistem (perceived ease of use) berpengaruh positif terhadap sikap pengguna (attitude) dalam pemanfaatan STI. 


\section{Persepsi Kenyamanan Pengguna (perceived enjoyment) dan Sikap Pengguna (Attitude)}

Sebuah sistem yang telah digunakan dalam jangka waktu yang lama oleh para pegawai untuk membantu menyelesaikan pekerjaan harian mereka akan memberikan kenyamanan ketika bekerja, dibandingkan dengan jika para pegawai melakukan pekerjaan mereka tanpa menggunakan teknologi informasi. Berdasarkan uraian diatas, maka dapat diturunkan hipotesis:

\section{$\boldsymbol{H}_{4} \quad$ :Persepsi kenyamanan pengguna (perceived enjoyment) berpengaruh positif terhadap sikap pengguna (Attitude) dalam pemanfaatan STI.}

\section{Persepsi Kemudahan Sistem (perceived ease of use) dan Pemakaian Nyata (actual usage)}

Kemudahan yang telah dirasakan oleh pengguna sistem informasi menimbulkan dampak positif bagi penggunaan sebuah sistem informasi yang terus meningkat. Dengan kata lain, pengguna sebuah sistem informasi tidak lagi sekedar menilai dan membandingkan dengan sistem informasi lain, tetapi pengguna sebuah sistem informasi sudah menjadikan sistem informasi yang telah dipakainya seperti sebuah alat yang dapat membantu menyelesaikan tugas dan pekerjaannya. Berdasarkan uraian diatas, maka dapat diturunkan hipotesis:

\section{$\boldsymbol{H}_{5} \quad$ : Persepsi Kemudahan Sistem (perceived ease of use) berpengaruh positif terhadap Pemakaian Nyata (actual usage) dalam pemanfaatan STI.}

\section{Pemakaian Nyata (actual usage) dan Persepsi Kegunaan (perceived usefulness)}

Manfaat yang telah diberikan oleh perusahaan melalui sebuah sistem informasi menyebabkan adanya peningkatan dalam penggunaan sistem informasi tersebut. Pengguna sistem informasi merasakan manfaat dalam penggunaan sebuah sistem informasi sehingga melakukan wujud nyata dari adopsi sebuah sistem informasi dengan cara terus menggunakan sistem informasi tersebut untuk menyelesaikan tugas dan pekerjaan mereka. Berdasarkan uraian diatas, maka dapat diturunkan hipotesis:

\section{$\boldsymbol{H}_{6} \quad$ :Persepsi Kegunaan (perceived usefulness) berpengaruh positif terhadap Pemakaian Nyata (actual usage) dalam pemanfaatan STI.}

\section{Persepsi Kegunaan (perceived usefulness) dan Penerimaan TI (acceptance of IT)}

Pengalaman kerja yang dimiliki oleh para pegawai menimbulkan kesadaran akan manfaat yang diperoleh para pegawai, dan akan merasa nyaman jika para pegawai menggunakan TI yang terintegrasi dalam melaksanakan aktivitas pekerjaannya. Berdasarkan uraian diatas, maka dapat diturunkan hipotesis:

\section{$\boldsymbol{H}_{7} \quad$ : Persepsi kegunaan (perceived usefulness) berpengaruh positif terhadap penerimaan TI (acceptance of IT) dalam pemanfaatan STI.}

\section{Sikap Pengguna (attitude) dan Penerimaan TI (acceptance of IT)}

Timbulnya minat untuk menggunakan sebuat sistem TI dipengaruhi oleh munculnya sikap awal terhadap sistem tersebut. Sikap awal yang positif akan mendorong minat yang semakin besar untuk menggunakan sistem tersebut, tetapi jika sikap awal adalah negatif maka akan dapat 
mengurangi minat dan ketertarikan seseorang dalam menggunakan sistem TI tersebut. Berdasarkan uraian diatas, maka dapat diturunkan hipotesis:

\section{$\boldsymbol{H}_{8} \quad$ : Persepsi Sikap Pengguna (attitude) berpengaruh positif terhadap Penerimaan TI (acceptance of IT) dalam Pemanfaatan STI.}

\section{METODE PENELITIAN}

Penelitian ini dilakukan terhadap karyawan bagian akuntansi dan keuangan yang bekerja pada Baitul Maal wa Tamwil (BMT) yang berada di wilayah Daerah Istimewa Yogyakarta dan sekitarnya. Teknik pengambilan sampel yang digunakan dalam penelitian ini adalah nonprobability sampling, yaitu teknik pengambilan sampel dengan kriteria tertentu. Adapun kriteria sampel yang dibutuhkan yaitu karyawan bagian akuntansi dan keuangan yang menggunakan STI di tiap BMT yang ada di wilayah Daerah Istimewa Yogyakarta dan sekitarnya. Peneliti mengambil sampel sebanyak 18 BMT dari 100 BMT yang ada di Wilayah Daerah Istimewa Yogyakarta dan sekitarnya.

\section{Model Pengukuran atau Outer Model}

Outer Modelyaitu bagaimana setiap blok indikator berhubungan dengan variabel latennya. Blok dengan indikator berhubungan dengan variabel latennya. Persamaan blok indikator refleksif adalah sebagai berikut:

$$
\begin{aligned}
& \mathbf{X}=\boldsymbol{\Lambda x} \boldsymbol{z}+\boldsymbol{\delta} \\
& \mathbf{Y}=\boldsymbol{\Lambda} \mathbf{y} \boldsymbol{\eta}+\boldsymbol{\varepsilon}
\end{aligned}
$$

Dimana $\mathrm{x}$ dan y adalah indikator atau manifest variabel untuk variabel laten eksogen $(\xi)$ dan endogen ( $\eta$ ). Sedangkan $\Lambda \mathrm{x}$ dan $\Lambda \mathrm{y}$ adalah matrik loading yang menggambarkan koefisien regresi sederhana dan menghubungkan variabel laten dengan indikatornya. Residual yang diukur dengan $\varepsilon x$ dan $\varepsilon y$ dapat didefinisikan sebagai kesalahan pengukuran atau noise.

\section{Model Struktural atau Inner Model}

Inner Modelmenggambarkan hubungan antara variabel laten berdasarkan pada substantive theory. Penulisan model persamaannya adalah sebagai berikut:

$$
\boldsymbol{\eta}=\boldsymbol{\beta} \mathbf{0}+\boldsymbol{\beta} \boldsymbol{\eta}+\boldsymbol{\Gamma} \xi+\zeta
$$

Dimana $(\eta)$ mendeskripsikan vector endogen (dependen) variabel laten, $(\xi)$ adalah vector variabel laten eksogen, dan $(\zeta)$ adalah vector variabel residual (unexplained variance).

\section{Wight Relation}

Wight Relation digunakan untuk menciptakan komponen skor variabel laten yang didapat berdasarkan bagaimana inner model dan outer model dispesifikasi. Penulisan model persamaannya adalah sebagai berikut:

$$
\begin{aligned}
& \xi_{b}=\sum_{k b} W_{k b} X_{k b} \\
& \eta_{i}=\sum_{k i} W_{k i} Y_{k i}
\end{aligned}
$$


Dimana Wkb dan Wki merupakan $\mathrm{k}$ wight yang digunakan untuk membentuk estimasi variabel laten $\left(\xi_{\mathrm{b}}\right)$ dan $\left(\eta_{\mathrm{i}}\right)$. estimasi variabel laten merupakan linear agregat dari indikator dengan nilai wight pada prosedur estimasi dispesifikasikan oleh inner model dan outer model. simbol ( $\eta$ ) merupakan vektor variabel laten endogen (dependen) dan simbol $(\xi)$ merupakan vektor variabel laten eksogen (independen), simbol $(\zeta)$ adalah vektor residual dan simbol $(\beta)$ serta $(\Gamma)$ merupakan matriks koefisien jalur (path coefficient).

\section{HASIL DAN PEMBAHASAN}

\section{Analisis Statistik Deskriptif}

Pengujian ini dilakukan untuk memberikan gambaran umum mengenai jumlah sampel, nilai minimum, nilai maksimum, rata-rata (mean) dan standar deviasi dari masing-masing variabel yang disajikan berikut:

Tabel 1 Deskripsi Statistik Data Penelitian

\begin{tabular}{|c|c|c|c|c|c|}
\hline & $\mathrm{N}$ & Minimum & Maximum & Mean & Std. Deviation \\
\hline Perceived Enjoyment & 40 & 9 & 15 & 12.50 & 1.155 \\
\hline Perceived Ease of Use & 40 & 20 & 29 & 23.98 & 1.761 \\
\hline Perceived Us efulness & 40 & 19 & 30 & 24.73 & 2.287 \\
\hline Attitude Toward Using & 40 & 15 & 25 & 20.20 & 1.897 \\
\hline Actual Usage & 40 & 6 & 15 & 11.80 & 1.620 \\
\hline Acceptanc e of IT & 40 & 15 & 29 & 22.55 & 2.810 \\
\hline Valid N (lis twise) & 40 & & & & \\
\hline
\end{tabular}

Sumber: output SPSS, 2017

\section{Hasil Uji Hipotesis}

Tabel 2 Result For Inner Weight

\begin{tabular}{cccccc}
\hline & $\begin{array}{c}\text { Original } \\
\text { Sampel } \\
(\mathrm{O})\end{array}$ & $\begin{array}{c}\text { Sample } \\
\text { Mean (M) }\end{array}$ & $\begin{array}{c}\text { Standard } \\
\text { Deviation } \\
(\text { STDEV })\end{array}$ & $\begin{array}{c}\text { T Statistics } \\
(\mid \text { O/STERR } \mid)\end{array}$ & P Values \\
\hline PEOU -> PU & 0,693 & 0,729 & 0,094 & 7,398 & 0,000 \\
PU - ATU & 0,385 & 0,311 & 0,297 & 1,298 & 0,196 \\
PEOU -> ATU & 0,337 & 0,396 & 0,338 & 0,995 & 0,321 \\
PE - A ATU & 0,126 & 0,148 & 0,148 & 0,855 & 0,394 \\
PEOU -> AC & 0,402 & 0,412 & 0,244 & 1,644 & 0,101 \\
PU -> AC & 0,327 & 0,342 & 0,229 & 1,426 & 0,155 \\
PU -> ACTI & 0,340 & 0,347 & 0,251 & 1,356 & 0,176 \\
ATT -> ACTI & 0,335 & 0,359 & 0,256 & 1,306 & 0,193 \\
\hline
\end{tabular}

Sumber: olah data PLS, 2017

\section{Persepsi Kemudahan Sistem (Perceived Ease Of Use) dan Persepsi Kegunaan (Perceived Usefulness)}

Persepsi pengguna tentang kemudahan dalam menggunakan sistem didukung oleh sikap pengguna tentang tentang kegunaan dari sistem tersebut. Hal ini dapat dipengaruhi oleh faktor masa kerja responden pengguna teknologi informasi dan masa implementasinya. Oleh karena itu, ketika responden menggunakan sebuah sistem teknologi informasi selama kurun waktu 5 tahun atau lebih, maka responden akan menganggap bahwa STI yang telah mereka gunakan mudah digunakan karena mereka telah mengetahui kegunaan STI tersebut. 


\section{Persepsi Kegunaan (perceived usefulness) dan pengguna (attitude)}

Persepsi kegunaan yang tidak berpengaruh signifikan terhadap terhadap sikap pengguna diduga karena suatu teknologi informasi yang telah lama digunakan pada suatu perusahaan akan membuat para penggunanya terbiasa dalam menggunakan teknologi informasi tersebut. Hal tersebut dapat dilihat berdasarkan usia pengguna, masa kerja, tingkat pendidikan serta lamanya sistem tersebut digunakan. Semakin lama sistem digunakan dan tidak dilakukan pembaruan maka pengguna teknologi informasi akan semakin terbiasa dalam menggunakan sistem tersebut karena pengguna sistem telah mengetahui kegunaan dari sistem yang mereka gunakan sehingga hal tersebut tidak membantu dalam meningkatkan kualitas, efektifitas, dan efisiensi kinerja para penggunanya.

\section{Persepsi Kemudahan Sistem (Perceived Ease Of Use) dan Sikap Pengguna (Attitude)}

Persepsi kemudahan sistem yang tidak berpengaruh secara signifikan terhadap sikap pengguna diduga karena perusahaan telah mewajibkan para karyawannya untuk menggunakan suatu sistem yang telah ditentukan agar para karyawannya dapat menyelesaikan pekerjaannya dengan baik. Sehingga peneliti menduga bahwa responden belum mengetahui tentang kejelasan tujuan dan kemudahan yang diberikan oleh sistem tersebut. Dengan demikian responden sering mengalami kesulitan dalam menyelesaikan pekerjaan mereka dengan baik dan tepat waktu.

\section{Persepsi Kenyamanan Pengguna (perceived enjoyment) dan Sikap Pengguna (Attitude)}

Persepsi kenyamanan pengguna tidak berpengaruh secara signifikan terhadap sikap pengguna. Peneliti menduga bahwa hal tersebut dikarenakan pemakaian sistem belum cukup lama dan responden masih cenderung melakukan aktivitas kerja mereka tanpa menggunakan sistem teknologi informasi yang tersedia. Sehingga responden masih perlu membiasakan diri untuk bekerja dengan menggunakan sistem informasi yang telah tersedia agar tercipta rasa nyaman dalam menyelesaikan pekerjaannya. Kemungkinan lain, peneliti menduga bahwa hal tersebut dikarenakan pengalaman kerja yang dimiliki, semakin lama pengalaman kerja yang dimiliki maka responden akan semakin nyaman dan terbiasa menggunakan sistem teknologi informasi dalam menyelesaikan pekerjaannya. Berdasarkan tabel 4.3 dapat diketahui bahwa 52,5 \% responden telah bekerja dibagian akuntansi dan keuangan selama kurun waktu $1-5$ tahun.

\section{Persepsi Kenyamanan Pengguna (perceived enjoyment) dan Sikap Pengguna (Attitude)}

Persepsi kemudahan sistem tidak berpengaruh secara signifikan terhadap pemakaian nyata. Peneliti menduga bahwa masih sedikitnya pengalaman kerja yang dimiliki maka responden belum merasakan kemudahan yang diperoleh dari suatu sistem yang digunakan untuk membantu menyelesaikan tugas dan pekerjaannya dalam durasi waktu yang telah ditentukan dan responden masih merasakan kemudahan jika melakukan aktivitas kerja mereka tanpa menggunakan sistem teknologi informasi tersebut. Sehingga responden cenderung menilai dan membandingkan antara sistem teknologi informasi yang digunakan dengan sistem informasi lain.

\section{Persepsi Kegunaan (perceived usefulness) dan Pemakaian Nyata (actual usage)}

Persepsi kegunaan tidak berpengaruh secara signifikan terhadap pemakaian nyata. Peneliti menduga bahwa responden belum merasakan manfaat dari suatu sistem, sehingga membuat intensitas penggunaan sistem tersebut menurun. Hal tersebut diduga karena tidak tersedianya informasi yang tepat dan memadai seperti yang sedang dibutuhkan oleh responden sehingga membuat responden harus mencari informasi yang dibutuhkan ditempat lain yang menyediakan informasi secara lebih akurat dan memadai. 


\section{Persepsi Kegunaan (perceived usefulness) dan Penerimaan TI (acceptance of IT)}

Persepsi kegunaan tidak berpengaruh secara signifikan terhadap penerimaan teknologi informasi. Peneliti menduga bahwa hal tersebut mungkin disebabkan oleh masih sedikitnya pengalaman kerja yang dimiliki responden belum menimbulkan kesadaran akan manfaat yang diperoleh responden dari suatu sistem yang digunakan untuk menyelesaikan pekerjaan berdasarkan informasi yang tersedia dalam sistem teknologi informasi tersebut. Hal ini membuat intensitas dalam penggunaan suatu sistem masih jarang.

\section{Persepsi Sikap Pengguna (attitude) dan Penerimaan TI (acceptance of IT)}

Sikap pengguna tidak berpengaruh secara signifikan terhadap penerimaan teknologi informasi. Peneliti menduga bahwa hal tersebut mungkin disebabkan karena munculnya minat awal yang negatif terhadap sistem teknologi informasi tersebut. Munculnya sikap awal yang negatif akan mengurangi minat dan ketertarikan responden dalam menggunakan sistem teknologi informasi untuk menyelesaikan pekerjaannya dengan baik, hal tersebut akan membuat responden tidak termotivasi untuk meningkatkan kinerjanya.

\section{KETERBATASAN PENELITIAN}

Penelitian ini tidak dapat terlepas dari beberapa keterbatasan. Keterbatasan tersebut diantaranya yaitu pertama kuesioner diberikan kepada responden melalui divisi HRD (Human Resources Development) disetiap kantor BMT, sehingga pada saat pengisian kuesioner responden tidak didampingi oleh peneliti. Peneliti juga tidak mengetahui apakah responden yang bersangkutan benar-benar mengisi kuesioner secara pribadi. Selain itu ada kemungkinan bahwa terdapat pernyataan-pernyataan yang ada didalam kuesioner yang kurang bisa difahami oleh responden dan membuat responden memberikan jawaban yang kurang sesuai dengan apa yang dimaksud dalam pernyataan kuesioner. Kedua, Kuesioner hanya didistribusikan pada BMT yang ada di Wilayah Daerah Istimewa Yogyakarta dan sekitarnya. Jangkauan penelitian yang sempit mengakibatkan hasil penelitian kurang bisa digeneralisasi.

\section{KESIMPULAN}

Berdasarkan hasil analisis data dan pengujian hipotesis dengan menggunakan bantuan program SmartPLS 3.0, maka dapat ditarik kesimpulan persepsi kemudahan sistem (perceived easeof use) berpengaruh positif secara signifikan terhadap persepsi kegunaan (perceived usefulness).Persepsi kegunaan (perceived usefulness)tidak berpengaruh secara signifikan terhadap sikap pengguna (attitude toward using). Persepsi kemudahan sistem (perceived ease of use) tidak berpengaruh secara signifikan terhadap sikap pengguna (attitude toward using). Persepsi kenyamanan (perceived enjoyment) pengguna tidak berpengaruh secara signifikan terhadap sikap pengguna (attitude toward using). Persepsi kemudahan sistem (perceived ease of use) tidak berpengaruh secara signifikan terhadap pemakaian nyata (actual usage). Persepsi kegunaan (perceived usefulness) tidak berpengaruh secara signifikan terhadap pemakaian nyata (actual usage). Persepsi kegunaan (perceivedusefulness) tidak berpengaruh secara signifikan terhadap penerimaan teknologi informasi (acceptance of IT). Sikap pengguna (attitude toward using) tidak berpengaruh secara signifikan terhadap penerimaan teknologi informasi (acceptance of IT. 


\section{DAFTAR PUSTAKA}

Adhiputra, M. W. (2015). Aplikasi Technology Acceptance Model Terhadap Pengguna Layanan Internet Banking. Calbi Socio Jurnal Bisnis dan Komunikasi, 2 (1), 55-56.

Brynjolfsson, E., \& Lorin, M. H. (1998). Beyond the productivity paradox, Association for Computing Machinery. Communications of the ACM; 41 (8), 49.

Cooper, D. R., \& P. S. Schindler. (2003). Business Research Methods. Eight Edition. McGrawHill/Irwin. New York, NY 10020.

Davis, F.D. (1989). Perceived Usefulness, Perceived Ease of Use dan Acceptance of Information System Technology. MIS Quartery, 13 (3), 319-339.

Dewi, S. \& Dwirandra A.A.N.B. (2013). Pengaruh Dukungan Manajemen Puncak, Kualitas Sistem, Kualitas Informasi, Pengguna Aktual Dan Kepuasan Pengguna Terhadap Implementasi Sistem Informasi Keuangan Daerah Di Kota Denpasar, Jurnal Akuntansi, Universitas Udayana.

Ferdinand, A. (2000). Structural Equation Modeling Dalam Penelitian Manajemen: Aplikasi Model-model Rumit dalam Penelitian untuk Tesis S-2 dan Disertasi S-3 BP Universitas Diponegoro, Semarang.

Gahtani S. S., \& Malcolm King. (1999). Attitudes, Satisfaction and Usage : Factors Contributing to Each in the Acceptance of Information Technology. Behaviuor dan Information Technology., 18 (4), 277-297.

Ghozali, I. (2014). Metode Alternatif Dengan Partial Least Square (PLS) dengan Program SmartPLS 3.0, Xlstat 2014 dan WarpPLS 4.0, BP Universitas Diponegoro, Semarang.

Goodhue, D.L., \& Thompson, R.L. (1995). Task-Technology Fit and Individual Performance. MIS Quarterly, 19 (2), 213-236.

Hair, Jr. J.F., Anderson, R. E., Tatham, R. L, \& Black, W. C. (1998). Multivariate Data Analysis. Fifth Edition. Prentice-Hall, Inc., New Jersey 07458.

Igbaria, M., Saroj, P., \& Badaway, M. K. (1994). Work Experience, Job Involvement, and Quality of Work Life Among Information Systems Personnel. MIS Quarterly, Juni, 175-201.

Istiarni, P. R. (2014). Analisis Pengaruh Persepsi Manfaat, Kemudahan Penggunaan Dan Kredibilitas Terhadap Minat Penggunaan Berulang Internet Banking Dengan Sikap Penggunaan Sebagai Variabel Intervening, Skripsi, Universitas Diponegoro.

Jogiyanto. (2003). Metode Penelitian Bisnis : Salah Kaprah dan Pengalaman- Pengalaman. Andi Offset. Yogyakarta

Kang, S. (1998). Information Technology Acceptance : Evolving with the Changes in the Network Environment. Center for information system management department of management science and information system graduate school of business. The University of Texas at Austin. IEEE.

Kessi, M., \& Andi S. (2004). Students Acceptance of Information Technology. UGM. Yogyakarta.

Morris, G. M., \& Dillon. A. (1997). How User Perceptions Influence Software Use. IEEE.

Muntianah S. (2012). Pengaruh Minat Perilaku Terhadap Actual Use Teknologi Informasi Dengan Pendekatan Technology Acceptance Model (TAM), Universitas Brawijaya, Malang.

Rigopoulos, G. \& Dimitrios, A. (2007). A TAM Framework to Evaluate User's Perception Toward Online Electronic Payments. Journal of Internet Banking and Commerce, 123.

Santoso, B. (2010). Pengaruh Perceived Usefulness, Perceived Ease Of Use, Dan Perceived Enjoyment Terhadap Penerimaan Teknologi Informasi. Tesis. Universitas Sebelas Maret.

Sathye, M. (1999). Adoption of Internet Banking by Australian Consumers: An Empirical Investigation, Journal of Bank Marketing, 17 (7).

Sekaran, U. (2006). Research Methods for Business. $4^{\text {th }}$ Ed. Jakarta. Salemba Empat.

Sharda, R., Barn S.H., \& Mc Donnell J.C. (1998). Decision Support System Effectiviness = A Review dan Empirical Test. Management Science, 32, II, 1492-1512. 
Suh, B. \& Han, I. (2002). The impact of customer trust and perception of security on the acceptance of electronic commerce. International Journal of Electronic Commerce, 7 (3), 135-161.

Syarif, D. I., \& Sensuse. (2007). Kajian Penerimaan teknologi Internet Pada Organisasi Pemerintah Berdasarkan Konsep Technology Acceptance Model (TAM): Studi Kasus Direktorat jenderal Pendidikan Islam Departemen Agama R.I, Jurnal Sistem Informasi MTI UI. 3 (1).

Szajna, B. (1996) Software Evaluation dan Choice: Predictive Validition of The Technology Acceptance Instrument. MIS Quarterly, 18, 319-324.

Tangke, N. (2004). Analisa Penerimaan Penerapan Teknik Audit Berbantuan Komputer (TABK) Dengan Menggunakan Technology Acceptance Model (TAM) Pada Badan Pemeriksa Keuangan (BPK) RI. Jurnal Akuntansi dan Keuangan, 6 (1). Fakultas Ekonomi Universitas Kristen Petra.

Weber, Ron. (1999). Information System Control And Audit. Prentice Hall.

Wijayanti, R. (2009). Analisis Technology Acceptance Model (Tam) Terhadap Faktor-Faktor Yang Mempengaruhi Penerimaan Nasabah Terhadap Layanan Internet Banking, Jurnal Akuntansi, Universitas Gunadarma.

Wilkinson, Cerullo., \& Wong, R. (2000). Accounting Information System. Fourth Edition, New York : John Wiley and Sons Inc.

Yuteva, S. (2010). Analisis Pengaruh Etika Kerja Islam Terhadap Komitmen Profesi Internal Auditor, Komitmen Organisasi, Dan Sikap Perubahan Organisasi, Skripsi, Universitas Diponegoro. 